which lead to the polar sea - between Greenland and Spitzbergen, between Spitzbergen and Novaya Zemlya, and through Behring Strait-and which have a physical connection, which is shown very distinctly in the isothermal curves. In this undertaking the co-operation of all States having an interest in these researches should be sought. Through the simultaneous action of different States a circle of observing points would be formed, which would sub-divide a common work having the same end in view, so that the combined labour of several nations would entail less sacrifice to each than has hitherto been the case. The Commission also recommends the above principles for the guidance of other nations, and thus an international alliance might be formed through which the highest scientific results would be attained. The Commission points out that one immediate result of the Second German Expedition is that the region between the west coast of Greenland and the east coast of Spitzbergen would be a suitable field for German research. As we have already stated (NATURE, vol. xiii., p. 33), they recommend a principal station to be established on the east coast of Greenland, with secondary stations on Jan Mayen Island and the west coast of Spitzbergen.

In the region indicated for observation, which can easily be reached from Central Europe, and whose exploration has for European States the greatest scientific and practical interest, German explorers have made a happy commencement, and established a claim for Germany to continue the work thus begun. The Commission urge Germany to set about at once fitting out an expedition for the occupation of the above region. They believe that if diligent preparations were made, the expedition might be ready to start in 1877 . Finally, they recommend the appointment of a Scientific Commission to draw up full instructions for the guidance of the expedition in all de partments.

\section{THE FAUNA OF THE CASPIAN SEA}

SCAR GRIMM has given in Von Siebold and Kölliker's Zeitschrift a brief account of his exploring expedition to the Caspian Sea last year, which will make naturalists look expectantly for the completion of his descriptions. The character of the fauna of the Caspian has interest for the evolutionist in natural history, as well as for the geologist. It will afford evidence not only of modification of animal life, but also of successions of change in physical geography. Two months were spent at Baku, and one month on board a steamboat in dredging from Baku to Krassnowadsk, thence to the Balchan Bay on the east coast, by the island of Tscheleki, southwards to Astrabad, and thence by Enzili and Lenkoran to Baku. Dredging was carried on up to a depth of I 50 fathoms, and an enormous quantity of specimens was obtained, including six new fishes (Gobius and Benthophilus), twenty spacies of Mollusca, including four species of Cardium, four of Adacna, and three of Dreyssena ; thirtyfive species of Crustacea, principally colossal forms of Gammarida ; and twenty species of Vermes. The eastern coast adjoining the sandy steppes was almost destitute of marine life, owing to the quantity of sand blown into the sea. The western part of the sea gives depths of 517 fathoms, and has a very abundant fauna. At one haul of the dredge in 108 fathoms, not far from Baku, there were taken 350 specimens of Gammaridæ, 150 Idothea entomon, fifiy co!ossal Mysis, six species of fishes, and many large Mollusca.

One hundred and twenty species in all were taken, of which eighty are new to science. Many more might be expected to reward dredgings in the deeper parts of the sea. Those already known fall into two classes : (I) those derived from still existing or already extinct species, or but slightly differing from species living in the nearest seas; and (2) those which are identical with those of other seas. The latter are spe zies possessing special tenacity of life, such as Sabellides octocirrate, Mysis relicta, and Idothea entomon.

Relationship is shown between the Caspian fauna and the faunas of the Aral and Black Seas, and the Northern Ocean. But the connection with the latter is more recent than with the Black Sea, for Phoca, Coregonus leucichtrys, and other forms, not existing in the Black Sea, are common to the Northern Ocean and the Caspian. The geographical changes which Dr. Grimm conceives to have brought about these results will be better understood, and their probability may be more easily criticised, when the complete account of the Caspian Fauna is published.

\section{NEW FORM OF TUBE FOR OBSERVING THE} SPECTRA OF SOLUTIONS*

WE have the honour of presenting to the Academy an eminently useful spectro-electric tube $;+$ it realises, in fact, a certain number of advantages, which are as follows :-

I. Constancy of spark permitting prolonged observation of spectra. 2. Suppression of the meniscus, and consequently of the ab. sorption which it produces by partly concealing the spark. 3. Electrodes enclosed in a special tube, which preserves the solution from contact with impurities. 4. Possibility of collecting entirely the substance examined. 5 . Possibility of arranging a series of spectroscopic tubes, enclosing solutions of the various bodies, thus permitting rapid demonstrations and comparisons.

The closed tube A of eleven 'centimetres in height, and $I_{\frac{1}{2}}^{\frac{1}{2}}$ centimetres in diameter, is traversed by a lower platinum electrode $f_{;}$in the mouth of $\mathrm{A}$ is fixed a cork stopper $\mathrm{C}$, pierced by an orifice through which passes a capillary tube $B . \quad B$ is traversed by a platinum wire $c d$, terminated at the upper end by a ring, and at the lower end by a point $d$, opposite $f . d$ and $f$ are the electrodes. The important part of the apparatus is a small capillary tube, slightly conical, one centimetre in height, moveable, and which covers the lower electrode $f$, topping it by $\frac{1}{2}$ millimetre.

To work the apparatus, pour into the tube $A$ the solution to be examined, taking care that the electrode $f$ and the tube $D$ are only immersed to half their height. Let $a b$ be the level of the liquid; capillary force determines the ascent as far as the point A, Tube into which the $D$, on which is formed an immovable poured B, Civillary drop which is vaporised when an in the platinum is fixed duction current is put on by $c$ and $f$. which forms the upper The observations may then continue a electrode. c, cork very long time without intermission, $A$; it supprors $B$, and allowing the spectra to be observed and permits its being moved $\begin{array}{ll}\text { drawn with the greatest ease. } & \text { with little friction. D, } \\ \text { Small capillary tube, }\end{array}$

This very simple apparatus has slighty conical, coverrendered us so great service in the ing the lower electrode course of our investigations, that we $f_{f}$, Lowerelectrode. $a b$, cannot too strongly recommend its Level of liquid. use to chemists engaged in spectral analysis. Never* Paper read at the Paris Academy of Sciences, Oct. 26, by MM. Delachanal and Mermet. Comptes Rendzs, t. Ixxxi. No. $x 7$, p. 726 . et de Physique" et de Physique," $5^{\mathrm{e}}$ series, t. iii, 1874 . 
theless, in some cases, as for example when it is desired to observe the spectrum of ferric solutions, it is preferable to employ the original tube ;* for the flow of the liquid causes solid particles to be given off, which tend to become fixed in the electrode.

\section{SCIENCE IN GERMANY \\ (From a German Correspondent.)}

$\mathrm{T}$ the twenty-fifih volume of the "Zeitschrift fuir Wissenschaftliche Zoologie," just completed, Ehlers has given some interesting conclusions with respect to the distribution of the Chrtopoda which were collected during the Porcupine expedition, by Messrs. Carpenter, Wyville Thomson, and Gwyn Jeffreys ("Beiträge zur Kentniss der vertical Verbreitung der Borstenwürmer im Meere "). He finds, in the first place, that of all Chætopoda occurring on the European coasts of the North Atlantic Ocean, only two families show representatives in the greater seadepths at more than 300 fathoms, and he thinks, therefore, it is not certain that any forms belong exclusively to the deep sea. Further, the conditions of temperature of the water, as they determine the horizontal distribution of Chrtopoda, seem also to be of influence with regard to their vertical distribution, seeing the deeper layers of water are also the colder. Accordingly the forms that live in the cold deep sea of that zone of the Atlantic Ocean correspond with those of the coast fauna of the Arctic regions; and Ehlers thinks that they might even have a direct connection through currents which descend from the Arctic regions to the depths of warmer marine zones. It is also conceivable that the deep-sea forms, at a time when those regions of the Atlantic were warmer than they are now, were frequenters of the coast, and in proportion as the Gulf Stream heated the upper layers, they retired into the depths. For the most part they remain inferior to their Arctic congeners, perhaps because the conditions of existence in the depths are less favourable, and partly, doubtless, on account of the lack of plant life, and also the small amount of animal nutriment for the worms, there provided. Though in the greater sea depths the light is quite excluded, yet in the Chretopoda found there (with some rare exceptions) we miss neither the colours nor the eyes, which are met with in coast regions. Ehlers believes that these colours and eyes are preserved in the lightless depths, in consequence of new animals ever migrating down from the brighter layers of water, and so preventing the disappearance of these bodyparts. There is, however, in the same "Zeitschrift" which contains Ehlers' work, a paper by the physiologist Ranke, on the eyes of leeches (Hirudo medicinalis), which may explain that phenomenon in the deep-sea Chætopoda in a different way "Beiträge zur Lehre von der UebergangsSinnes-Organen "). Ranke, on the ground of his observations on living leeches, considers that their very simply constructed eyes have also sensations of touch and taste ; and, further, that they are not eyes proper, which, on occasion, also serve other ends; they are, rather, neutral organs of sense, which can act in various directions, but in no particular one so specially as sense organs more highly organised, and therefore limited to one specific energy. This appears partly from the fact that organs quite similar to these so-called eyes on the head of the leech occur also in the whole of the rest of its body, quite in the same way as the so-called side organs of fishes and amphibia, which probably afford sensations of touch. We might, then, regard the eyes of the deep-sea Chrotopoda as similar indifferent organs of sense, which, even where light fails, do not discontinue their functions. In an appendix to his memoir, Ehlers further describes how the tubeworms (Tubicola) construct their abodes. They use their feelers only for seizing and holding the building materials,

- See "Annales de Chimie et de Physique," Third Series, t. iii., $\times 874$. then press these to the mouth or side of the abdomen, where they are coated with a cement secreted from numerous skin-glands in these parts of the body. So prepared, the piece has merely to be pressed on a firm bed, or the edge of a tube already formed, and there it adheres. In this way not only are new tubes constructed, but also any damages are repaired.

\section{NOTES}

THE following are the probable arrangements for the Royal Institution Friday evening meetings before Easter 1876 :Jan. 2I, Prof. Tyndall, F.R.S.: The Optical Deportment of the Atmosphere in relation to the Phenomena of Putrefaction. Jan. 28, Prof. Huxley, F.R.S. : The Border Territory between the Animal and the Vegetable Kingdoms. Feb. 4, W. H. Preece: The Applications of Electricity to the Protection of Life on Railways. Feh. II, William Crookes, F.R.S. : The Mechanical Action of Light. Feb. 18, Dr. C. William Siemens, F.R.S.: The Action of Light on Selenium. Feb. 25, Lord Lindsay : The Transit of Venus. March 3, Earl Stanhope, F.R.S.: The Ancient Sun Worship, and the Remains of it in England. March Io, Prof. W. H. Flower, F. R.S. : The Extinct Animals of North America. March 17 , Sir Henry Sumner Maine, K.C.S.I. : The Later History of the Fief and Manor. March 24, Prof. Oaling, F.R.S. (subject not announced.) March 31, Edward B. Tylor, F.R.S. : Ordeals and Oaths. April 7, Prof. Jas. Dewar, F.R.S.E. : The Physiological Action of Light, Part II. The following lecture arrangements have been made:-Christmas Lectures (adapted to a juvenile auditory) by Prof. Tyndall, F.R.S. : Six lectures on Experimental Electricity. In this course the phenomena of frictional electricity will be so illustrated and its principles so explained as to enable the pupil to repeat the experiments, and to pursue the subject further, at school or at home. With this object in view the laws of the science will be elicited from facts obtained with the simplest apparatus. Prof. A. H. Garrod Twelve lectures on the Classification of Vertebrated Animals. Dr. J. H. Gladstone, F.R.S. : Eight lectures on the Chemistry of the Non-metallic Elements. Dr. W. Spottiswoode, Treas. R.S. : Four lectures on Polarised Light. R. P. Pullan: Three lectures on his Excavations in Asia Minor. W. T. Thiselton Dyer: Four lectures on the Vegetable Kingdom; the Boundaries and Connections of its Larger Groups. Prof. G. Croom Robertson: Three lectures on the Human Senses. Edward Dannreuther: Two lectures on Wagner and his Trilogy (with pianoforte illustrations).

THE Stockholm $N_{y} a$ Dagligt Allebantla of the $4^{\text {th }}$ inst. contains some account of the return voyage of the Pröven from the mouth of the Yenesei, after the departure of Nordenskjöld. The information is sent by Dr. Théel Kjellman, to whom, it will be remembered, Nordenskjüld gave over the command of the Pröven. The Pröven left Dickson Harbour, at the mouth of the Yenesei, on the I 9 th August, and set her course towards the north-east part of Novaya Zemlya. On the 23rd August she was found to be already in $75^{\circ} 24^{\prime} \mathrm{N}$. lat., and $66^{\circ} 24^{\prime}$ long. E. from Greenwich, and so a little to the south of Cape Middendorf, on the north-east coast of Novaya Zemlya. This peculiar circumstance can only be explained by a very strong northwesterly current going from the $\mathrm{Ob}$ and Yenesei out over the Kara Sea. At Cape Middendorf, where ice was met with which extended eastwards as far as the eye could reach, the expedition was becalmed for six days. During this time a considerable amonnt of dredging work was done, with abundant results. That animal life is here uncommonly rich at the seabottom may be inferred from the fact that when a swab was allowed to remain in contact with the bottom for a few minutes it was covered over with animals : sea.stars by hundreds, with 